\title{
"A Deterrent to Vagabonds, Lazy Persons and Promiscuous Individuals" : Control and Discretion in the Norwegian Workhouse System, 1845-1907
}

Frode Ulvund

\section{(2) OpenEdition \\ Journals}

Electronic version

URL: http://journals.openedition.org/chs/1357

DOI: $10.4000 /$ chs. 1357

ISSN: 1663-4837

Publisher

Librairie Droz

\section{Printed version}

Date of publication: 1 December 2012

Number of pages: $29-54$

ISBN: 978-2-600-01642-1

ISSN: 1422-0857

Electronic reference

Frode Ulvund, " "A Deterrent to Vagabonds, Lazy Persons and Promiscuous Individuals" : Control and Discretion in the Norwegian Workhouse System, 1845-1907 », Crime, Histoire \& Sociétés / Crime, History \& Societies [Online], Vol. 16, n² | 2012, Online since 01 December 2015, connection on 20 April 2019. URL : http://journals.openedition.org/chs/1357 ; DOI : 10.4000/chs.1357 


\section{"A Deterrent to Vagabonds, Lazy Persons and Promiscuous Individuals"}

\section{Control and Discretion in the Norwegian Workhouse System, 1845-1907}

\section{Frode Ulvund ${ }^{1}$}

Entre 1845 et 1907, le système norvégien des maisons de correction était basé sur une Loi des Pauvres autorisant la police à y enfermer des vagabonds pour une durée maximale de six mois. Ces mesures relevaient de la discrétion policière, sans aucune intervention judiciaire. Cette pratique ne fut sérieusement remise en question que vers la fin $d u X I X^{e}$ siècle, ce qui conduisit à l'abolition de ce dispositif. Cet article présente le système des maisons de corrections de 1845 à 1907, décrivant ses fonctions et examinant le pouvoir discrétionnaire de la police dans un pays dont la constitution prohibait tout châtiment sans procès. La thèse de l'article est que cet enfermement discrétionnaire fournissait à la police et aux collectivités locales un instrument commode pour agir contre des fauteurs de désordres. Il argue également que les entraves croissantes apportées à ce pouvoir entre 1894 et 1907 devaient davantage au souhait des professionnels du droit de mettre la législation en conformité avec l'État de droit qu'à leur préoccupation pour la sécurité juridique des pauvres et vagabonds soumis à l'enfermement. Les objectifs de ce dernier et ses cibles demeurèrent les mêmes, bien que l'enfermement en maison de correction perdît de son efficacité après que le pouvoir discrétionnaire de la police eût été limité.

Between 1845 and 1907, the Norwegian workhouse system was based on the Poor Law which authorised the police to detain vagrants for up to six months in the workhouse. These measures were enforced on the basis of police discretion without any judicial proceedings. Only towards the end of the nineteenth century was this practice seriously questioned, ultimately leading to the abolition of the discretionary workhouse system. This article presents the Norwegian workhouse system from 1845 to 1907, outlining its functions, and discussing the discretionary power placed in the hands of the police in a country whose constitution forbade punishment without legal trial. The article argues that discretionary detention was regarded as a flexible instrument that allowed the police and local communities to intervene against

\footnotetext{
Frode Ulvund is Associate professor in history at the University of Bergen, Norway. He specialises in the field of the history of crime and of forced labour. Currently he is working on a project researching the impact of Director General Bernhard Getz on the discourse of and practise of forced labour in the 1890s in Norway. Recent publications include "En aabenbar Chikane"? Ole Bulls konflikt med politiet i Bergen i 1850', in Bergen-Bull-Bergenserne. Bergen, Bodoni, (2010), "En Skole, hvori han forhærdes istedetfor at forbedres". Straffanstaltkommisjonens beretning om tukthuset i Bergen fra 1841', in Bergens historiske forenings skrifter (2011) and "At rense gaterne", Tvangsarbeid som disiplinering og sosial kontroll før 1907, in Virker straff?, forthcoming anthology at Scandinavian Academic Press (2012).
} 
disorderly individuals. It also argues that the increased limitations on the police's discretionary power between 1894 and 1907 were motivated by a legal-professional wish to adapt the legislation to comply with prevailing principles of the rule of law rather than concerns for the legal protection of the paupers and vagrants who were subjected to detention. The aims and the groups targeted for detention remained the same, although workhouse detentions turned out to be less efficient when the police discretions were curtailed.

\section{INTRODUCTION}

Oser $\mathrm{n}$ a Tuesday in June 1864, a father filed a complaint against his two daughters, Severine, who was 23 years of age, and Bernhardine Jensen, who was 21, due to their idleness ${ }^{2}$. The complaint led to interrogation of the girls at the police station, and both were issued with a warning. They were told that unless they had some form of employment by mid-summer, both would face detention in the local workhouse. Bernhardine eventually found employment as a maid, while her sister ended up in the Bergen Workhouse because of idleness and immoral conduct ${ }^{3}$.

Ten years later, in March 1874, Ingebrigt Monsen was released from the Bergen Workhouse. He and his brother had been locked up there since two days before New Year, a period of time only interrupted by a ten-day prison term at the end of January. After two days as a free man, Ingebrigt was again united with his brother, this time locked up in the workhouse for two months. Ten days later, the brother was released, but being homeless, he was arrested for vagrancy later that same night. Unable to pay for the night in prison, the police declared him without legal means of subsistence and sent him for two months to the workhouse on the basis of a discretionary police decree ${ }^{4}$. The brothers were detained and united again on a seemingly regular basis. Between 1864 and 1889, the two of them were detained no less than seventy-five times in the workhouse, for periods between one and six months. In addition they both accumulated several prison sentences. Their father and mother also had occasional residency at the workhouse.

Between 1845 and 1907, when a new Vagrancy Act came into effect, forced labour in workhouses was authorised by the Norwegian Poor Law of 1845. The law enabled the police to detain vagrants, who were defined in the law as "addicted to idleness and drunkenness" and thus not able to provide for themselves ${ }^{5}$. The workhouse inmates could be kept locked up for as long as six months on the basis of an administrative and discretionary decision by the police alone, and before 1894 this did not require any written justification. In the larger Norwegian towns, the scale of detention under the Poor Law was considerable. In the 1890s, there were about ten workhouses in Norway; the one located in the capital Kristiania (Oslo)

2 Bergen State Archive (BSA), Politimesteren i Bergen, 'Forretningsjournal' No.4, 1863-1865 (Government Document), 14.6.1864.

3 BSA, Politimesteren i Bergen, 'Forretningsjournal' No.5, 1867-1870, BSA, Politimesteren i Bergen, 'Forretningsjournal' No.5, 1867-1870 2.10.1867.

4 BSA, Politimesteren i Bergen, 'Forretningsjournal' No.8, 1874-1875, 23.3.1874.

5 Lov om Fattigvasenet i Kjøbstader 20.sept.1845 [Urban Poor Law 1845], §45, and Lov om Fattigvasenet paa Landet 20.sept.1845 [Rural Poor Law 1845], § 76. 
was by far the largest ${ }^{6}$. By the mid-1880s, about 1100 persons out of a population of 2 million were detained annually, and of these 700 were held in the capital ${ }^{7}$. The numbers went down towards the end of the Poor Law regime, but were still seven to eight times higher than in the years after the 1907 repeal of discretionary detentions.

As Paul Lawrence has pointed out in his article on the policing of the poor in England and France, police attitudes were rigid and harsh toward vagrants during the latter half of the nineteenth century, reflecting prevailing social anxieties in those countries ${ }^{8}$. This was equally valid for much of Europe, and Norway was no exception. Already in 1844, one of the architects of the Norwegian Poor Law declared that the purpose of the workhouse was to be "a deterrent to vagabonds, lazy persons and promiscuous individuals, who cannot be controlled"9. Furthermore, he admitted that neither economic benefit nor any lasting moral improvements could be expected from such detentions. Yet, he emphasised that detention safeguarded society against troublesome persons and at least made them contribute something to their own upkeep.

While criminalisation of vagrancy has a long history, and the continuous war against vagrancy was characterised by repeated waves of policy offensives, the measures implemented during the second half of the nineteenth century are particularly interesting. Industrialisation and the transformation of the labour market, with its emphasis on mobile, wage-earning labour, inevitably led to a reconceptualization of unemployment and idleness, since unemployment was considered fundamentally different from being unwilling to work. The free movement of labour was encouraged and older laws obstructing such mobility across regions were liberalised or repealed in order to create national labour markets. As workers increasingly depended on wages and were vulnerable to industrial economic cycles, the question of how to deal with involuntary unemployment became increasingly pressing. This was important also in order to facilitate the social integration and political loyalty to nation states of the emerging wage-earning classes as the suffrage was expanded.

Concurrently, the image was constructed of an increasing urban residuum inflicting great social and moral harm to society at large. This led to widespread demands for heavy-handed measures against those who were seen as unwilling to work. As a consequence, it became essential to distinguish between different types of able-bodied individuals without employment. The aim was to facilitate and help, rather than pauperise, "honest" people who were looking for work, and to discipline and control the remaining "hard-core" of professional vagrants. The template was the German network of work stations (Wanderarbeitsstätten or NaturalVerpflegungsstationen), where migrants looking for work were provided with shelter on the condition that they followed a strict itinerary and subjected themselves to a work test ${ }^{10}$. The English Casual Wards had a similar purpose. In Norway, this resulted in the new Vagrancy Act sanctioned by the king in 1900, which removed the repressive measures towards vagrants from the Poor Law and reduced the stigma of receiving relief - a change that was embraced by labour-friendly groups

\footnotetext{
6 Before 1925, Oslo was named "Christiania"/ "Kristiania".

Figures from Getz (1887, p. 55).

Lawrence (2004).

Blom, Bassøe (1844, p. 55).

10 Frohman (2008).
} 
as well ${ }^{11}$. The Vagrancy Act itself, however, was highly unpopular within the labour movement, where it was considered to be class specific legislation that criminalised unemployment. Trade unions also feared that it would be used as a weapon against collective actions, such as strikes ${ }^{12}$. Effectively, a dual jurisprudence evolved. On the one hand, individual liberties were strengthened as the rule of law and due process guaranteed the interests of "respectable" citizens, while arbitrary and extra-juridical interventions were legitimised as deterring measures against the "residuum" who represented a threat to the social order.

The police were an essential agent in implementing these measures, and considerable power was laid in their hands. Usually some level of discretion was employed when police monitored lifestyles or acts considered to be immoral or debauched and not in line with the expectations of the "respectable" working class. Discretion was often institutionalised, granting administrative authorities, notably the police, the right to order the confinement of drunkards or vagrants without involving the legal system at all. This was the case in Norway; yet there were other examples of administrative detention from parts of Switzerland, as described by Sabine Lippuner ${ }^{13}$. Switzerland did not have federal legislation regulating workhouse detentions. Each canton decided the procedures regionally, which included judiciary and administrative proceedings as well as detention by adjudication. Some cantons became notorious for applying administrative Versorgung as late as 1981. Such levels of administrative discretion were rare in Europe, as in most countries administrative internments were supervised and could be appealed to the legal system, or delegated from it. The Prussian Penal Code of 1851 authorised the police to detain former prisoners convicted of prostitution, begging, vagrancy or for being work-shy for as much as two years ${ }^{14}$. The Imperial German Penal Code of 1871 curtailed these powers, but discretion was still integrated into the legal process. When vagrants were sentenced to prison, judges could leave to the police to decree additional workhouse detention after the end of the prison term. Warren Rosenblum argues that the persistence in Germany of such discretion demonstrates that the police concern for controlling prostitution and vagrancy took precedence over juridicalliberal principles of due process and justice ${ }^{15}$. Larry Frohman has argued that lack of clear rules regarding the delegation of such power by judges as well as uncertainty about the circumstances under which the police was supposed to impose additional corrective internment led to arbitrary enforcement ${ }^{16}$. He also points out that judges, aware of the incomplete information available to them, hesitated to delegate decisionmaking to police discretion unless the person in question was regarded as hardened and incorrigible. As a consequence, arguments were raised in German - especially Prussian - debates in favour of introducing administrative detention without recourse

Seip (1994, p. 164).

12 Newspaper Social-Demokraten 22.05.1900 and Stortingets forhandlinger; Dokument No.100; Forestilling fra "Arbeidernes faglige Landsorganisation i Norge" angaaende odelstingets beslutning til lov om løsgjængeri, betleri og drukkenskab (1899-1900). [Records of Proceedings of the Storting, Document No.100; 1899-1900. Petition from labour union regarding the Vagrancy Act].

13 Lippuner (2005).

14 Rosenblum (2008, p. 20).

15 Ibidem.

16 Frohman (2008). 
to the courts. While such suggestions were rejected during the imperial era out of concerns for principles of individual freedom, the discussion continued during the Weimar Republic.

Far more common was the informal discretion when authorities at different levels enforced regulations on vagrancy. This was particularly the case for authorities who were in daily contact with the target groups of such regulations. Stefan Petrow emphasises this point when arguing that the individual policeman exercised wide discretion at street level when considering whether or not to arrest a drunken person ${ }^{17}$. Not only were the circumstances of the vagrant decisive, so too were considerations of how an arrest might inconvenience the police constable, who would have to appear in court while off duty. Paul Lawrence illustrated this point by the pragmatic attitudes of both English and French policemen ${ }^{18}$. The introductory example in this article, with the police issuing oral warnings to potential detainees, demonstrates this pragmatism at work. Hans Wallentin argues that the scope of unprotocolled warnings towards vagrants increased in Sweden in the early twentieth century, thus transforming control into a matter between the police and the vagrant - control that was detached from formal institutions ${ }^{19}$.

The level of discretion exercised in the everyday policing of laws and morals was obviously considerable. The expansion and professionalization of police and state bureaucracy from the mid-nineteenth century facilitated the internalisation of social control and discipline outside the framework of the courts. This placed immense powers in the hands of the police when they monitored morals and vagrancy, even where discretion was not formally sanctioned by law, and made social control less apparent to the wider society.

The scope for discretionary police powers places the Norwegian example in a special category when compared to the workhouse systems elsewhere in the Western world, including other Scandinavian countries. The distinctive character of workhouse detentions in Norway was also acknowledged by contemporaries within the political and legal sphere. In 1892 the Norwegian Attorney General, Ole Anton Qvam commented that the discretionary practice of forced labour in Norway was without parallel in any other country ${ }^{20}$. Thus, the Norwegian example calls for a closer scrutiny. The aim of this article is to present the Norwegian workhouse system in the period 1845-1907, to outline its functions, and discuss how the scope of discretionary power vested in the police through punishment without trial was incompatible with the Norwegian constitution. The article suggests that the workhouse system was regarded as an effective instrument to control and render harmless the lower urban strata, which was often labelled as dangerous to society. It further argues that the workhouse, and thus the police itself, was to some extent also an instrument employed by neighbours and families to place the responsibility for disorderly individuals upon the authorities. This dual function of workhouse detention helps explaining why the scope of discretion was surprisingly uncontroversial among contemporaries. The early twentieth-century reforms of the workhouse

\footnotetext{
Petrow (1994, p. 216).

Lawrence (2004, pp. 222-223).

Wallentin (1989, p. 66).
}

20 Stortingets forhandllinger; Forhandlinger i Odelstinget, 8. del (1892, p. 423). [Records of Proceedings of the Storting 1892, Parliamentary debate]. 
system, which required a court verdict prior to internment, were partly motivated by a desire among an elite within the legal profession to adapt the legislation to comply with prevailing principles of the rule of law. Reforms were not guided by concerns for the legal protection of the paupers and vagrants who were subjected to detention. An additional motivation was to remove the "unrespectable" paupers from the Poor Law in order to lessen the stigma of poor relief among unemployed workers, as the concept of unemployment changed in the latter part of the nineteenth century. This legal modernisation was regarded as inevitable, according to many administrators of the forced labour system, but also deplorable because it obstructed a practice considered to be both efficient and useful for social control. The forging of the new Vagrancy Act, in force from 1907, as well as the discussions leading up to it, illustrates prevailing attitudes towards the workhouse inmates, the detentions they were exposed to, and the intended function of this practice in the final decades of the nineteenth century.

\section{SCANDINAVIAN WORKHOUSES BEFORE THE WELFARE STATE}

In many respects, all Scandinavian countries experienced similar developments with regards to social policy from the end of the nineteenth century, as they evolved into welfare states that are often labelled the Nordic welfare state model. This process started in the latter part of the nineteenth century, although at first the extent and content of welfare institutions were limited. During the formative stages of the welfare state it was important to develop effective instruments to distinguish between those worthy of receiving public relief and those who were not; and the Scandinavian countries all adjusted their instruments during this period.

In the early nineteenth century there were three different institutions in Norway involved in incarceration: prisons, bridewells (tukthus), and "slaveries". The prisons were normally not used for punishment, but as custody houses for those awaiting trial. The bridewells were mixed institutions rooted in the handling of the poor. From the mid-eighteenth century, the bridewells were closely integrated with policies towards the poor. Local authorities were obliged to round up all vagrants and ship them to the nearest bridewell after a trial. In 1789, when bridewells became the normal punishment for thefts, the institution shifted its main character from an institution for social control to a penal institution.

With the new Penal Code in 1842, the bridewells were exclusively used as penal institutions, and they were detached from any connection with the poor laws. From 1842 onwards, the bridewells were filled with convicted criminals sentenced to penal servitude of six months or more. Men sentenced to six years or more, served their time under military command in a fortress. Such prisoners were referred to as "slaves", and the fortress prisons as "slaveries". Moreover, with the Penal Code, local prisons shifted from functioning mainly for custody to short-term imprisonment.

In 1842, the new Penal Code severed the ties between the bridewells and the Poor Law, as well as the opportunity to detain so-called "unworthy" paupers. However, the government was obviously not willing to abandon this instrument altogether, and allowed local authorities to establish new workhouses, which were founded on the Poor Law of 1845. The law allowed for the incarceration of convicted beggars; but the most important target was the social residuum among the urban proletariat. In other words, a simple administrative decree, without any involvement from the 
judicial system, allowed the police to detain individuals for periods up to six months, if they were known to be idle or alcoholic, and hence suspected to be without legal means of subsistence. The decision was final and there was no opportunity for appeal. Furthermore, until 1894, there was no requirement for the police to provide a formal justification. The only criterion was age, as the detained person had to be above 15 years of age.

The ability to summarily detain vagrants generated little discussion in the 1840s, and these powers were largely uncontested until the 1890s. The parliamentary committee that prepared the law did discuss whether it was in violation of the constitution, but concluded that detention in a workhouse was not to be regarded as punishment, but as a measure benefitting the inmate as much as the community in which he or she lived ${ }^{21}$. A committee revising the Poor Law in the late 1850 s and early 1860s expressed some scepticism of the discretionary powers vested in the local police. However, proposals to place some limitations around these powers were met with fierce resistance among local authorities and quickly abandoned by government ${ }^{22}$. Only in the final decade of the nineteenth century was this practice seriously questioned, and the procedures slightly revised, as the discretionary practices of the police were to be supervised by the Department of Justice. The discretionary instrument provided by the Poor Law was in place from 1845 right until 1907, when a new Vagrancy Act came into force that introduced judicial decisions for such cases. Thus, Norway maintained discretionary detention against the "dangerous" poor for a longer period than most countries ${ }^{23}$. The workhouse sentence for vagrancy was abolished as late as 1970 .

The experience of being in workhouse detention was very similar to being imprisoned in institutions that applied penal servitude with hard labour. The inmates were dressed in workhouse uniforms, locked up and guarded day and night. The daily routines were similar to those in a prison, as was the type of work. Typical work for male detainees consisted of oakum picking, stone breaking, or some handicraft production, while spinning, weaving, or household duties were undertaken by the female inmates. Irregular behaviour could lead to disciplinary actions, including whipping. A major difference between workhouses and penal institutions was that workhouses did not operate with classification and separation of inmates - a practice that was increasingly implemented in the penal institutions. Major reforms from the 1850s modernised Norwegian prisons in accordance with the Philadelphia System, and numerous new prisons were erected in the 1860s based on the principles of isolation and classification. The criticism of the old prisons never included challenges to the similarly organised workhouses. The argument was that most workhouse inmates were incorrigible, and therefore cohabitation day and night caused no further moral contamination. According to the committee charged with estimating the workhouse capacity required following the new Vagrancy Act of 1907, the main purpose of the workhouse was not to facilitate rehabilitation, but to detain vagrants so that society "got rid of them for a shorter or longer period"

\footnotetext{
21 Recommendation by the standing Church Committee in the Norwegian Parliament dated 9.8.1845, here quoted from Midré (1990, p. 101).

22 Ulvund (2002, p. 398).

23 See Hippel (1906, p. 107ff).

24 Om istandbringelse af nye tvangsarbeidsanstalter: indstilling fra den af Justisdepartementet 28de september 1905 nedsatte komite (1907, p. 9).
} 
Detention in workhouses during the latter part of the nineteenth century has not received much attention in the Scandinavian historiography. It has been partly addressed in relation to topics such as unemployment and poverty. Forced labour as a measure against vagrants had its obvious parallels in other Scandinavian countries. In both Denmark and Sweden, forced labour was an instrument used towards a class of people similar to those targeted in Norway. The Norwegian Department of Justice also actively collected information from the neighbouring countries when they considered reforming the practice of forced labour. However, the scope for discretion laid down in the Norwegian workhouse system in the latter part of the nineteenth century was unparalleled elsewhere in Scandinavia.

In Sweden, it was compulsory for every individual to have laga försvar ("legal protection") until the Vagrancy Act of 1885. This meant that individuals had to produce evidence either by a reference from an employer or by other means, that they were able to support themselves. Those unable to provide such a guaranty were regarded as vagrants and could be sentenced to forced labour ${ }^{25}$. Unemployment was thus effectively criminalised among the poor. The Vagrancy Act of 1885 authorised the royal district governors to decree the detention in a "workhouse for idle persons" of those who were not searching for work. A precondition for detention was that the person had been officially warned within the last two years ${ }^{26}$. Such decisions were delegated to local police authorities, but had to be presented to the governor for approval. If a vagrant resisted detention, the case could be appealed to the Supreme Court of Sweden. As a result, forced labour in Sweden was in a much stronger sense encapsulated by judicial restraints in comparison with forced labour in Norway; in Sweden, a senior authority supervised the decrees and each individual had the opportunity for court recourse. Nevertheless, the administrative influence on detention in Swedish workhouses also raises questions about the legality of the procedures, as the Swedish constitution, like the Norwegian, forbade imprisonment without a conviction.

The transition from laga försvar to the Vagrancy Act after 1885 has been the focus of interest for some researchers. Jonas Olofsson discussed the significance of the "work approach" in Swedish social policy during a period when the labour market was liberalised and temporary unemployment was not only unavoidable, but also necessary ${ }^{27}$. According to Olofsson, the motive behind the Vagrancy Act was to distinguish between those who were involuntarily unemployed and those who represented a threat to society such as vagrants and criminals ${ }^{28}$. He argues that under the new law, the vagrants lived with the constant threat of being criminalised and put under tutelage. Likewise, Roddy Nilsson shows that the Vagrancy Act and the repeal of laga försvar dissolved the close bonds between the regulation of vagrancy and the

\footnotetext{
See Wallentin (1989).
}

26 Swedish Vagrancy Law of 12.6.1885, §2. See also Wallentin (1989, p. 12).

27 The "work approach", or "arbetslinjen" in Swedish, refers to various initiatives aimed at increasing labour market participation and emphasises the importance of such participation in the Nordic countries.

28 Stortingets forhandlinger; Dokument No.100; Forestilling fra "Arbeidernes faglige Landsorganisation i Norge" angaaende odelstingets beslutning til lov om løsgjængeri, betleri og drukkenskab (1899-1900). [Records of Proceedings of the Storting, Document No.100; 1899-1900. Petition from labour union regarding the Vagrancy Act]. 
labour market ${ }^{29}$. He argues that the main function of the Vagrancy Act was to uphold order, and the aim was to control and authorise detention of persons presumed to be a threat to order and public safety. In this sense, the Swedish workhouse system had obvious parallels to the Norwegian system, although it was not as flexible because the decrees were supervised and could be appealed.

In Denmark the Act on Vagrancy and Begging of 1860 and the Poor Law of 1891 constituted the main legislation authorising forced labour ${ }^{30}$. According to the Vagrancy Act vagrants could be detained in workhouses, but only following a conviction. The Poor Law extended the scope for forced labour by sanctioning administrative detention when individuals who were receiving poor relief conducted their lives in violation of public order and decency. This practice was in accordance with the Danish Constitution. Poor relief was a constitutional right, but the condition imposed limitations in the personal freedom of the pauper ${ }^{31}$. Detention in a workhouse was just one example of such limitations, and thus considered to be constitutional.

Lars Andersen has discussed the concept of unemployment that prevailed in Denmark around 1900. He argues that in the discourse of unemployment, this referred to a social problem that needs to be understood in relation to middle-class moral condemnation of unemployment as a moral breach and a form of deviance ${ }^{32}$. As in Sweden and in Norway, the hallmark of public labour market policy was to separate the unworthy and unwilling from those worthy and willing to work. The poor were to be disciplined and educated in order to live well-ordered and temperate lives. The emphasis was on improving work ethics, and workhouses were among the instruments for instilling discipline. As such, Andersen highlights the disciplinary function of the workhouse on the working class in general.

\section{NORWEGIAN WORKHOUSE INMATES: MARGINALISED AND DANGEROUS?}

Although Norwegian workhouses were founded on the Poor Law, they had little to do with aiding the poor, as outdoor relief was the predominant form of relief. Yet, to some destitute people it could be a last voluntary refuge, especially in the cold and harsh seasons. It is unclear whether all paupers who approached the police and asked to be sent to the workhouse had their wishes granted. All the requests that appear in the police journal were cases in which access to the workhouse was granted, yet some requests may have been dismissed without being entered in the journal. Once admitted, however, these destitute individuals were regarded as regular inmates and were not allowed to leave the institution before they had served the period decreed by the police.

The most important groups of inmates were people with alcohol addiction, homeless individuals, petty criminals, and domestic troublemakers. They could all be detained against their will, although sometimes they entered the workhouses

Nilsson (2003, p. 219).

30 Law of 3.3.1860 and Law of 9.4.1891.

31 Danish Constitution of 5.6.1849, §89.

32 Andersen (2005). 
on their own request. Among female detainees, prostitutes constituted the most prevalent group.

Workhouse detention was an urban phenomenon. As many as 97 per cent of male and 99 per cent of female inmates in the period from 1901 to 1906 were registered in an urban municipality ${ }^{33}$. The workhouses were located in towns, and for rural authorities, it was both inconvenient and costly to transport potential inmates over long distances. Moreover, detentions were costly, as the state only paid a portion of the expenses. Consequently, local authorities in rural areas often pursued a strategy of shifting vagrants across parish borders.

Numerous reports and witnesses claimed that most male inmates suffered from alcoholism. One example came from the workhouse chaplain in Bergen. He stated in 1880 that the male inmates were generally profoundly alcoholic and most had a socalled "weak" character ${ }^{34}$. As long as they stayed in the workhouse, they remained sober, but once back in the street, they fell back into old habits when they were re-exposed to their alcoholic friends. For many, it was only a couple of days before they found themselves arrested and back in the workhouse again. While criminals received some help and financial support upon release from penal institutions, the workhouse inmates received nothing. The consequences were unsuitable lodgings, if any, and the company of old drinking-friends as their only social network outside the workhouse. In addition, bad reputation and ailing health from years of alcohol abuse made it difficult for them to find, not to mention retain, any form of work. Prejudices against them were often worse than those faced by criminals, thus constituting a situation that was not so different from Eric Monkkonen's depiction of the poorhouse in Columbus, Ohio, in the second half of the nineteenth century. Monkkonen describes the paupers as being at the very bottom of the so-called "dangerous class" within the United States ${ }^{35}$.

Contemporaries often highlighted the link between alcoholism and petty crime. This is vividly demonstrated in a quote by a workhouse chaplain of an inmate's description of his and his friends' routines in the town of Trondheim: "When we embark on a drinking binge we keep on till all the money is gone; then we pawn our clothes, and then finally we steal for drinks" ${ }^{36}$. The majority of male inmates also got a criminal conviction at some point in their life, most often because of theft or disorderly and violent behaviour ${ }^{37}$. A number of persons were also locked up in the workhouse for being suspected of criminal acts, where the police was unable to prove guilt. One example concerned the prostitute Nille Nielsdatter. The police journal tells us that she was arrested in Bergen in March 1857 under suspicion of having committed theft. By the time of her arrest, she was intoxicated. She was released the following day on account of inconclusive evidence, but was then detained in the local workhouse for six months ${ }^{38}$. Another example was Johan Mikkelsen, who

\footnotetext{
33 Norges offisielle statistikk, Fengselsstyrelsens Aarbog, Kristiania [Oslo] 1901-1906 [Official Statistics of Norway].

34 Norwegian National Archives (NNA): Justisdepartementet, Fengselsstyret, Kontor D, Db. L0120/ 3A 115 2/2, 'Tvangsarbeidsanstalter, Bergen 1872-1907'. Innberetning 1880.

35 Monkkonen (1975, pp. 155-164).

36 Hval (1884, p. 196).

37 See Ulvund (2002).

38 BSA, Politimesteren i Bergen, 'Forretningsjournal' No.1, 1856-1857, 11.3.1857.
} 
was arrested in 1858 under suspicion of burglary. He was released due to lack of evidence. However, because he was without financial means, clothes, or permanent work, he was sent to the workhouse for six months ${ }^{39}$. Evidence suggests that this reflects a form of punishment in cases where police was convinced of guilt, but unable to prove the criminal act in court.

Although the police was empowered to detain without conviction due to their administrative prerogatives, and most often without a formal justification, it was probably rare to find people being detained in workhouses completely by chance. Being excessively drunk and bad mannered during a night out normally resulted in a fine or possibly a night in jail, but did not lead to detention in a workhouse for months. Only when this behaviour became repetitive, or when the police suspected a criminal lifestyle, could the workhouse be a possible outcome.

As the data in Table 1 suggest, the majority of male inmates in the Bergen workhouse were well into adulthood. In every decade between 1850 and 1888, the group aged between 30 and 59 was overrepresented, compared to the overall age distribution in the population according to the Bergen census of 1865. This is consistent with trends found elsewhere, such as the Trondheim workhouse where 65 per cent of male inmates between 1850 and 1867 were between 30 and 59 years $\mathrm{old}^{40}$. While the elderly were also overrepresented, the figures clearly indicate that the majority of inmates were probably able-bodied men. Compared to those charged with criminal offences, the workhouse inmates were much older, as 57 per cent of those charged with a criminal offence in Norway between 1846 and 1885 were under 30 years of age, compared to 23.8 per cent among the workhouse inmates in Bergen between 1850 and $1888^{41}$.

Table 1: Male age distribution in Bergen Workhouse 1850-88 and the 1865 census of Bergen.

\begin{tabular}{|c|c|c|c|c|c|c|c|c|c|c|}
\hline & \multicolumn{2}{|c|}{$15-29$ years } & \multicolumn{2}{|c|}{$30-59$ years } & \multicolumn{2}{|c|}{$>=60$ years } & \multicolumn{2}{|c|}{ Unknown } & \multicolumn{2}{|l|}{ Sum } \\
\hline & $\mathrm{n}$ & $\%$ & $\mathrm{n}$ & $\%$ & $\mathrm{n}$ & $\%$ & $\mathrm{n}$ & $\%$ & $\mathrm{n}$ & $\%$ \\
\hline $1850-59$ & 272 & 25.0 & 711 & 65.3 & 105 & 9.7 & & 0.0 & 1088 & 100.0 \\
\hline $1860-69$ & 317 & 21.6 & 949 & 64.7 & 182 & 12.4 & 19 & 1.3 & 1467 & $100, .0$ \\
\hline $1870-79$ & 407 & 21.6 & 1131 & 60.2 & 308 & 16.4 & 34 & 1.8 & 1880 & 100.0 \\
\hline $1880-88$ & 363 & 28.4 & 721 & 56.3 & 195 & 15.2 & 1 & 0.1 & 1280 & 100.0 \\
\hline $1850-88$ & 1359 & 23.8 & 3512 & 61.5 & 790 & 13.8 & 54 & 0.9 & 5715 & 100.0 \\
\hline 1865 Census & 4033 & 40.0 & 5007 & 49.6 & 934 & 7.8 & 112 & 1.1 & 10086 & 100.0 \\
\hline
\end{tabular}

Sources: Bergen Byarkiv [Bergen County Archive] Fattigvesenet. Arbeidsanstaltens arkiv, 1. 'Hovedregister 1843-49', 2. 'Hovedregister 1847-70', 3. 'Hovedregister 1868-76', 4. 'Hovedregister 1876-89' and Digitalarkivet [The Digital Archive - http://www.digitalarkivet.no], Bergen census 1865.

$39 \quad$ BSA, Politimesteren i Bergen, 'Forretningsjournal' No.2, 1858-1860, 1.5.1858.

40

The Digital Archive [http://www.digitalarkivet.no]: 'Tvangsarbeidarar i Trondheim 1850-1867'.

${ }_{41}$ Norges offisielle statistikk, Tredie Række No. 73, Oversigt over de vigtigste Resultater af Norges Kriminalstatistikk for Aarene 1846-85. Kristiania [Oslo] 1888, p. 20 [Norwegian Official Statistics]. 
Typically, workhouse inmates were single. In Oslo, 80 percent of all male inmates between 1866 and 1869 were unmarried ${ }^{42}$. Likewise, in Bergen in the period from 1876 to 1888 , where more than 80 percent of male inmates above the age of 40 were either unmarried (61 percent) or in a post-marital stage as a widower or divorcee (20 percent $)^{43}$. This was a considerable overrepresentation compared to the general urban population. The 1875 census of Bergen shows that only 24 percent of males above the age of 40 were unmarried. This difference is hardly coincidental. As one can expect higher levels of social control within the matrimonial framework as well as a sense of familial responsibility towards spouse and children, family and marital bonds most likely constituted an important stabilising factor which prevented people from engaging in the kind of lifestyles that relegated men to workhouse detention. In addition, the male workhouse detainees were hardly the most attractive prospective husbands and consequently, their opportunity to establish a family deteriorated over the years. The workhouse inmates were often marginalised characters who inhabited the fringes of society, where they experienced problems with both family and work relationships.

The workhouse represented a spiral of despair and destitution, as well as a tool for social control and discipline. Once released from a workhouse, the former inmates were under police surveillance, people from the local community hesitated to employ them, and they often found companionship among other former workhouse inmates. The length of time between release and return to the workhouse was likely to narrow as the number of stays in the workhouse - whether voluntarily or involuntarily increased. The workhouse inmates were regarded as outcasts of society, and from the perspective of the police, the workhouse was an efficient instrument to cleanse the streets of these elements.

The profile of female detainees did not mirror that of the male inmates, as the females were generally younger, less prone to crime, and less frequently inebriated. The majority of female inmates were under 30 years of age (Table 2) and 72 percent were under 40 by the time of their detention. Similarly, in Trondheim where 70 percent of the women detained in the workhouse between 1850 and 1867 were under the age of $40^{44}$. Over time, the female workhouse population in Bergen became younger, and in the $1880 \mathrm{~s}, 70$ percent of them were aged under 30 . The difference in age distribution among the sexes mirrored different causes of their detentions. The primary reason for detention of women was prostitution ${ }^{45}$. In 1879, the workhouse chaplain in Bergen explained to the government in his first annual report on the moral conditions in the workhouse that, to his surprise, all the women in the workhouse, with a few rare exceptions, were "public" girls, i.e. prostitutes ${ }^{46}$. Official statistics show that 84 percent of the 1,364 women detained in Norwegian workhouses between 1901 and the summer of 1907 made their living from prostitution ${ }^{47}$.

\footnotetext{
$42 \quad$ Sundt, Christophersen (1978, p. 151).

43 Ulvund (2012).

44 The Digital Archive, (http ://www.digitalarkivet.no): 'Tvangsarbeidarar i Trondheim 1850-1867'.

45 Ulvund (2002).

46 NNA: Justisdepartementet, Fengselsstyret, Kontor D, Db. L0120/3A 115 2/2, ‘Tvangsarbeidsanstalter, Bergen 1872-1907'. Innberetning 1880.

47 Norges offisielle statistikk, Fengselsstyrelsens Aarbog, Kristiania [Oslo] 1901-1906 [Official Statistics of Norway].
} 
Table 2: Female age distribution in Bergen Workhouse, 1850-88 and the 1865 census of Bergen.

\begin{tabular}{|c|c|c|c|c|c|c|c|c|c|c|}
\hline & \multicolumn{2}{|c|}{$15-29$ years } & \multicolumn{2}{|c|}{ 30-59 years } & \multicolumn{2}{|c|}{$>=60$ years } & \multicolumn{2}{|c|}{ Unknown } & \multicolumn{2}{|l|}{ Sum } \\
\hline & $\mathrm{n}$ & $\%$ & $\mathrm{n}$ & $\%$ & $\mathrm{n}$ & $\%$ & $\mathrm{n}$ & $\%$ & $\mathrm{n}$ & $\%$ \\
\hline $1850-59$ & 121 & 43.5 & 137 & 49.3 & 19 & 6.8 & 1 & 0.4 & 278 & 100.0 \\
\hline $1860-69$ & 110 & 37.0 & 161 & 54.2 & 25 & 8.4 & 1 & 0.3 & 297 & 100.0 \\
\hline $1870-79$ & 246 & 64.6 & 113 & 29.7 & 18 & 4.7 & 4 & 1.0 & 381 & 100.0 \\
\hline $1880-88$ & 313 & 70.3 & 105 & 23.6 & 25 & 5.6 & 2 & 0.4 & 445 & 100.0 \\
\hline $1850-88$ & 790 & 56.4 & 516 & 36.8 & 87 & 6.2 & 8 & 0.6 & 1401 & 100.0 \\
\hline 1865 Census & 4334 & 36.3 & 5893 & 49.4 & 1639 & 13.7 & 71 & 0.6 & 11937 & 100.0 \\
\hline
\end{tabular}

Sources: Bergen Byarkiv [Bergen County Archive] Fattigvesenet. Arbeidsanstaltens arkiv, 1. 'Hovedregister 1843-49', 2. Hovedregister 1847-70, 3. 'Hovedregister 1868-76', 4. 'Hovedregister 187689' and Digitalarkivet [The Digital Archive - http://www.digitalarkivet.no], Bergen census 1865.

Prostitution was illegal in Norway until a new penal code came into force in 1905. However, as in many countries, it was quietly accepted as long as it took place according to certain regulations. In the larger towns there were brothels with official rules regulating the conduct and control of prostitutes, and all women suspected of prostitution were under disciplinary and medical surveillance. As elsewhere in Europe, the system was motivated by the market and demand for sexual services, and regulations attempted to control the spread of venereal diseases.

Women failing to comply with these rules seldom faced criminal charges for prostitution. Instead, the workhouse was used to discipline known or suspected prostitutes who behaved inappropriately. With its simplified procedures and lack of requirements for evidence, the workhouse was a very efficient instrument to control disorderly prostitutes. The workhouses were also central for controlling venereal diseases and some of them had separate wards for treating venereal diseases. How important the detention of prostitutes was became clear after 1894 when police discretion in these matters was partly curtailed with the introduction of written justifications for administrative detention and requirements that the authorities should demonstrate that the detainees was a burdens to society. The prostitutes seldom received poor relief. Local police voiced concern and the government soon adopted a more lenient attitude towards the discretion performed. Furthermore, when the new Vagrancy Act, with its judicial requirements, was evaluated in 1914, one of the complaints put forward pertained to the difficulties it had caused in controlling prostitution. The repeal of the prostitution section in the Penal Code was enacted in 1905, which naturally intensified the difficulties in controlling prostitution. In $1914 \mathrm{a}$ former chief constable in Bergen explained the attempts by the police to circumvent this by charging the women for alcohol addiction instead of prostitution, but they had failed in this effort because of the lack of medical evidence that could stand up to scrutiny in court ${ }^{48}$.

$48 \quad$ Stortingets forhandlinger, Oth. prp. No.14 (1914, p. 14). [Records of Proceedings of the Storting. Proposition to the Storting (Bill) No. 14, 1914, on amendments to the Vagrancy Act]. 
As mentioned previously, the authorities and the police regarded the workhouse as a very efficient instrument for cleansing the streets of undesirable elements and for controlling certain groups among the lower classes of the towns. Shortly after the workhouse closed in Bergen, the chief constable explained how efficient the workhouse had been in this respect, and also emphasised how the institution was utilised for informally punishing habitual criminals who committed crimes, but where the police were unable to prove their guilt ${ }^{49}$.

Detention with the purpose of rendering the person harmless was from the beginning a central function of the workhouse. As presented in the introduction, this aim was already expressed by members of the committee who drafted the Poor Law. The sources of moral contamination - and the medical contamination with regard to prostitutes - had to be removed from the public sphere. A commission preparing a revision of the Poor Law concluded in 1856 that the purpose of the workhouse was to fight "moral degradation in general", in addition to idleness, drunkenness, and begging ${ }^{50}$. This struggle against moral degradation was not put into print in any formal code, but there is no doubt that the police had this in mind when administering the Poor Law and the workhouse institutions.

The same outlook was implicit in the reforms at the end of the century, of which many were initiated by Bernhard Getz. He was a brilliant law professor, who served as Director General of Public Prosecution from 1889 to 1901. Most of that time, he was on leave from his position as Public Prosecutor in order to focus on several major legal reforms and worked both within and outside the commission appointed for the revision of the Penal Code. As a major influence on legislative reforms and as the principal architect of most of the major social and penal bills at the time, Getz played a key role in forming policies of the emerging social liberal state. In 1893 he clearly expressed his view on the workhouse inmates in a draft to the new Penal Code:

If vagabonds are the curse of the countryside, the criminal proletariat of day workers are the plague of the larger towns; persons who spend their days in idleness or in the bars, living from theft, income from female prostitution or their own, sleeping rough or in half built houses, everywhere being a danger to people's safety, public moral and personal property ${ }^{51}$.

Morally and socially speaking, the workhouse inmates were considered as less worthy than the majority and as outcasts of society. Alexander Kielland, the Norwegian novelist who was also a critic of the workhouse system, explained in 1889 that the workhouse was "a regular residence for the 'outcast' of society, people who had seen all phases of degradation and humiliation, people that society had written off and who had given up on themselves" 52 .

The workhouse was not only an instrument in the hands of the authorities and the police. Though most workhouse inmates were without family ties, and many were without fixed dwelling, the initiative to have the person detained could emanate

Olsen (1914, p. 349).

50 Betæenkning og Indstilling fra den ved Kongelig Resolution af 5te August 1853 nedsatte Commission angaaende det offentlige Fattigvasen pasa Landet (1856, p. 111).

51 Getz (1893, p. 127). The quotes in this article are translated from Norwegian to English by the author.

52 Kielland (1889). 
from sources other than police authorities. To some the workhouse was a last resort to which they applied for admission, but this group seems to have increased over time. In the 1850s and 1860s, about 10 percent of the inmates in Oslo had requested detention, according to a contemporary survey ${ }^{53}$. During the second half of 1894 , the police journals stated that as many as 70 percent were detained voluntarily in $\mathrm{Oslo}^{54}$. These are the figures after the new regulations of 1894, which restricted police discretion, especially in cases involving involuntary detention.

The workhouse was also employed to control unruly family members or individuals in the local community. The importance of neighbours as agents of social control - displaying both the ability and the willingness to intervene in disputes and disorderly conduct - has been emphasised by several historians. Vincent Sleebe noted that social control within a neighbourhood or other kinds of local communities was above all intended to keep every member in line ${ }^{55}$. In this sense, social control primarily concerned the community members and such intervention were characterised by informality. However, Sleebe emphasised that the borderline between informal social control, as exercised by people "among themselves", and formal control, as exercised by institutions and authorities, was vague. The blurred line becomes obvious when the formal control at the local level was exercised by officials with personal links to or even representing the neighbourhood in other respects. Furthermore, in his study of neighbourhoods in eighteenth-century Paris, David Garrioch has argued that community interventions in disputes were common and even expected, or at least accepted ${ }^{56}$. Garrioch emphasises how disputes between neighbours tended to be noisy and often occurred in public or semipublic places, such as streets, courtyards, or stairs chaises. Disputes, if not resolved between the participants or after peer intervention, might result in an appeal to the local commisarie, and thus slide into the grey zone between formal and informal social control. Similarly, the study of Catharina Lis and Hugo Soly of the eighteenthcentury Austrian Netherlands demonstrates the importance and willingness of neighbours and families in requesting forced removal of unruly members of the local community ${ }^{57}$.

The studies by Garrioch and by Lis and Soly refer to pre-modern societies. The modernisation during the nineteenth century has been described as a decline in the importance of local communities due to dynamic urbanisation and growing importance of privacy within the domestic sphere. This modification also influenced the role of the neighbourhood as an agent for social control, especially when it came to intervening in domestic quarrels or marital violence, where battered wives were increasingly isolated and left to their own fate. Elizabeth Foyster has strongly

53 Sundt, Christophersen (1978, p. 146).

54 Transcripts from police journals from the police in Kristiania, 3rd and 4th quarter of 1894. NNA, S-1043, Justisdepartementet, Fengselsstyret D del 1, L0157 'Toftes gave 1880-1900. Oppgave over innsatte i tvangsarbeidsanstalt 3. kvartal 1894. Fengselsregnskap'; NNA: S-1043 Justisdepartementet, Fengselsstyret D del 1, L0158 'Oppgave over innsatte i tvangsarbeidsanstaltene 1894-1895' 3A $1152 / 6$, departementet's review of detentions from Kristiania 4. quarter 1894.

55 Sleebe $(2004$, p. 171).

56 Garrioch (1986, pp. 16-55).

57 Lis, Soly (1996). 
rejected this view, arguing that violence was a mechanism by which family matters became community concerns, even in the modernising city ${ }^{58}$.

The evidence from Norwegian workhouses supports this conclusion as it was a mechanism in the regulation of social norms within local communities. The workhouses were infamous among urban dwellers, and in many cases, the mere threat to report someone to the police could be an effective method of exercising informal social control within the neighbourhood. At the same time, this obviously did not apply to all situations, and the police journals relate several stories where local communities acted against their disorderly members, illustrating incidents of breakdown of informal control in the local community. Wives reported their inebriated and violent husbands, husbands likewise reported their wives, parents reported their children, neighbours reported each other, etc. The two sisters, mentioned in the introduction, who were reported to the police by their father is one of many examples where family members reported each other. Another case was Helene Andersen, who in December 1858, was detained in the workhouse after being accused of domestic disturbance and violent behaviour towards her mother ${ }^{59}$. In May 1863, Lauritz Bang was arrested for assaulting his wife ${ }^{60}$. The wife appeared before the police, requesting that her husband should move out of their home. The police ordered the husband to refrain from alcohol and unruly behaviour and he was warned that he would be detained if further complaints were presented. In another 1863 case, a customs worker in Bergen requested that the police send his wife Christine to the workhouse ${ }^{61}$. He claimed that she was addicted to alcohol and had already been to the workhouse several times, as well as in prison. They had four children, and three of them were already relocated to foster parents. The fourth child had also been in care, but the husband was now responsible for the child. He claimed to have no other alternative than to send the child away again, unless his wife was sent to the workhouse. The story was backed by his landlord, so police granted the husband's request and the wife was detained for six-months. In July of the same year, a barrel maker was reported for domestic disturbance and drunkenness, as well as for being a nuisance both to his wife and to the other tenants in the house ${ }^{62}$. He was detained for two months.

Bergen was a town with cramped quarters and the residents had little privacy. Consequently, an unruly family member also meant an unruly neighbour. Some neighbours acted to help a beaten wife, but also to keep order in the neighbourhood. Sometimes that meant reporting troublemakers to the police and requesting their removal from the local community via workhouse detention. The sources from Bergen reveal numerous examples of the police granting such requests from families or local communities, demonstrating the workhouse as an instrument of social control among the residents of an urban area in the process of rapid modernisation. The appeals to the police represented both formalisation and extension of social control, which contributed to the complex picture of neighbourhood control as described by Sleebe.

\footnotetext{
Foyster (2005, p. 168).

59 BSA, Politimesteren i Bergen, 'Forretningsjournal' No.2, 1858-1860, 9.12.1858.

60 BSA, Politimesteren i Bergen, 'Forretningsjournal' No.2, 1858-1860, 20.5.1858.

61 BSA, Politimesteren i Bergen, 'Forretningsjournal' No.4, 1863-1865, 2.7.1863.

62 BSA, Politimesteren i Bergen, 'Forretningsjournal' No.4, 1863-1865, 1.7.1863.
} 
Thus, the workhouses in Norway had multiple functions for a range of groups within society. It was an instrument available to the police in cleansing the streets of undesirable elements, as well as an instrument that allowed neighbours and families to shift the responsibility for disorderly people to the authorities as a last resort. Although the Norwegian workhouse system was founded upon the Poor Law, it had little to do with aiding the poor. It was primarily an instrument of social control, discipline, and social renovation, with the purpose of removing the threat from "the outcast" and protecting society. Towards these individuals, the workhouse system constituted a complete transfer of authority over their lives into the hands of the police - a power that was not controlled by the legal system and was arguably in violation of the constitution. The discussions erupting in the 1890s about workhouse detention and police discretion, which eventually brought about the repeal of administrative decrees, illustrate that internment and social renovation were the institution's major functions - one that overshadowed any attempt of rehabilitation.

\section{UNCONSTITUTIONAL DETENTIONS?}

Far-reaching discretionary power is, of course, also a problematic tool to maintain in a state that is supposed to be governed by the rule of law. A central feature of such a law-governed state is that no one can be tried for conduct that is not prohibited by law, and no one can be punished without a conviction confirming that such a violation has taken place. These principles were proclaimed by the Norwegian Constitution of 1814 , and the courts were accountable to these principles. However, this was not the case for workhouse detentions, which illustrates the dual jurisprudence that evolved during the nineteenth century.

As mentioned above, the workhouse system was a flexible solution for the authorities and local communities to intervene against disorderly people or potential criminals, and the system had a clear function of removing the threat constituted by marginal groups of society. Bernhard Getz, the Director General of Public Prosecution, also stated that the benefit of workhouse detention was the opportunity to prevent potential criminals from breaking the law in the future ${ }^{63}$. Given the discretionary power granted to the police, it was far more convenient to discipline and detain than to punish. The inability of the workhouse to rehabilitate pointed in the same direction, according to Getz. He believed that the maximum length of detention of six months was too short, both for those who could potentially turn away from old habits and even more so for those who frequently returned to the workhouse and for whom there was no hope of improvement. Moreover, reform was hampered by the constant release and return ${ }^{64}$.

It might have been a conscious choice to exclude forced labour in workhouses from debates on penal reform. As long as the authorities could prevent workhouse detention from being defined as punishment, they could also avoid the legal problem regarding the protection of inmates. The legislators were not oblivious to the problem and briefly discussed the legality of the workhouse clause of the Poor Law. They worked around the breach of the Constitution by defining detention in workhouses as

\footnotetext{
63 Getz (1893, p. 118, footnote 1).

${ }^{64}$ Getz (1893, p. 127).
} 
compulsory care and as more a benefit to the inmate than a punishment. As a result, the parliamentary committee that prepared the Poor Law Bill in 1845 discussed whether administrative decisions on forced labour violated the constitution. They rejected this objection because "detention in a workhouse should not be considered as a punishment, but as an arrangement for the benefit of the inmate, as well as for society in general" ${ }^{65}$. These strategies for legitimising discretionary detentions were quite similar to those that prevailed in Switzerland at the same time, as described by Sabine Lippuner ${ }^{66}$.

The constitution did not require a judicial ruling before care was provided to a citizen. Transferring this definition to workhouse inmates was regarded as somewhat dubious by contemporary critics, but it was not seriously questioned in public debates. After years of harsh life with alcohol abuse and lack of proper housing, the inmates themselves were often so reduced in their physical and mental capacities that they were unable to articulate public protests against the workhouse policies. Nevertheless, violent conduct by inmates within the workhouses was often linked to disgruntlement over their detention on the basis of police discretion ${ }^{67}$.

The fact that workhouse detention was not to be regarded as punishment did not prevent officials and politicians from using penal terminology when referring to such internment. Before the amendment of the Poor Law in 1863, a parliamentary committee declared that the purpose of forced labour in workhouses was "a punishment for begging and vagrancy that can be applied alongside or in replacement of imprisonment" ${ }^{6}$. The committee also recommended that local authorities combined prisons and workhouses since these were "in many respects linked institutions" ${ }^{69}$. The prison chaplain in Bergen also consistently referred to the inmates as "prisoners" and described their stay in the workhouse as "punishment". Even Director General Bernhard Getz admitted in 1893 that the workhouses were "penal institutions in which people can be detained on discretion" $" 70$.

The problematic question regarding the lawfulness of workhouse detention was briefly addressed by the commission working on the amendment of the Poor Law of 1863 . They claimed that, to their knowledge, the police had not abused their discretionary power towards workhouse inmates ${ }^{71}$. Nevertheless, the commission recommended that regional governors should approve all cases of detention in order to "avoid abuse"72. Initially, the government supported this view, recognising the disadvantages of granting to a subordinate authority "such an extent of discretionary power, which is currently vested in the police". Government authorities also

65 A proposal by the standing Church Committee in the Norwegian Parliament dated 9.8.1845, here quoted from Midré (1990, p. 101).

66 Lippuner (2005, pp. 48-52).

67 Omsted (1911).

68 Stortingets Forhandlinger; Indst. O. No.28 (1862-1863, p. 109). [Records of Proceedings of the Storting 1862-1863; Recommendation No.28 from the standing Church Committee regarding amendments to the Poor Law].

69 Ibidem.

$70 \quad$ Forhandlinger ved den norske kriminalistforenings andet mode i oktober 1893 (1894, p. 118).

71 Betcenkning og Indstilling fra den ved Kongelig Resolution af 5te August 1853 nedsatte Commission angaaende det offentlige Fattigvasen paa Landet (1856, p. 113).

72 Betcenkning og Indstilling fra den ved Kongelig Resolution af 5te August 1853 nedsatte Commission angaaende det offentlige Fattigvasen paa Landet (1856, p. 114). 
regarded the proposed control by the regional governor as a positive change ${ }^{73}$. In his response to the proposed amendments, the regional governor of Kristiansand in the south of Norway declared that he could not support deprivation of freedom without any legal process. In his opinion a legal process with judicial examinations and court ruling was preferable to regional governors consenting to decisions made by the police. Moreover, he thought that a legal ruling was necessary because the law allowed the boards of workhouses to use imprisonment as a tool for disciplining unruly inmates ${ }^{74}$.

Nevertheless, there were additional objections against including workhouses in the penal system. The regional governor of Jarlsberg and Laurvig, also in the south of Norway, claimed that it had never been a problem that the police had this power, and the involvement of the regional governor in the process would only delay detentions without adding any advantages ${ }^{75}$. The Board of Guardians in Oslo made exactly the same assertion. The board of Guardians, which governed the Oslo workhouse and held the authority to release inmates when advisable, testified that the chief constable of Oslo had never abused his discretionary power. As evidence they claimed that they had never released anyone who was not qualified for detention. They argued that involving regional governors would only lead to overwhelming workloads for the governor and great increase in police paperwork ${ }^{76}$. A regional administrative board for eastern Norway (including Oslo), which had among its members the local bishop and the regional governor, came to the same conclusion. They argued that oversight by the governor of police decrees would only lead to an enormous increase in bureaucracy without any clear benefits ${ }^{77}$.

Faced with these objections, the government abandoned its original position, although acknowledging that workhouse detention without proper legal process was problematic. Consequently, the discretionary power of the police survived the Poor Law amendment in 1863. It was more important to keep workhouse detention as an efficient instrument than to protect the civil rights of the inmates. Symptomatically, the question of civil rights and the constitution was never discussed when the bill was passed through the Norwegian Parliament.

With its summary procedure prior to detention, the workhouse supported the interests of the police as social agents and the ruling elite, as well as local communities in dealing with disorderly individuals at the expense of the civil rights of workhouse inmates. In 1914, the chief constable of Bergen acknowledged this priority when looking back on the system: "Admittedly, though the discretionary power of the

73 Stortingets Forhandlinger; Indst. O. No.28 (1862-1863, p. 80). [Records of Proceedings of the Storting 1862-1863; Recommendation No.28 from the standing Church Committee regarding amendments to the Poor Law].

74 Stortingets Forhandlinger 1862-1863, Indst. O. No.28 (p. 37). [Records of Proceedings of the Storting 1862-1863; Recommendation No.28 from the standing Church Committee regarding amendments to the Poor Law].

75 Ibidem.

76 Stortingets Forhandlinger; Indst. O. No.28 (1862-1863, p. 78f). [Records of Proceedings of the Storting 1862-1863; Recommendation No.28 from the standing Church Committee regarding amendments to the Poor Law].

77 Stortingets Forhandlinger; Indst. O. No.28 (1862-1863, p. 79). [Records of Proceedings of the Storting 1862-1863; Recommendation No.28 from the standing Church Committee regarding amendments to the Poor Law]. 
police to deprive people of their freedom without any legal process was not abused, theoretically it was not reassuring [....]"78 The legal framework for forced labour in workhouses was not changed until the new Vagrancy Act of 1900 came into force in 1907. In the drafting process that began in the late 1880s, the problems regarding the legal rights of inmates were discussed more seriously by people in positions of authority.

\section{THE COMING OF THE VAGRANCY ACT OF 1900}

The appointment of a new Criminal Law Commission in 1885 paved the way for the new Vagrancy Act. As the primary drafter of the law, Bernhard Getz was the driving force in the commission, and he had a decisive influence on the content and aims of the law. The commission dealt with vagrancy as early as 1887 in a draft for a new criminal code and revisited the question in a draft from 1893, in which forced labour continued to be the principal form of sanction against vagrancy ${ }^{79}$. In 1892, Getz discussed the articles concerning drunkenness in a draft of a new law against promiscuity and venereal diseases ${ }^{80}$. At this time, the use of forced labour in workhouses became a heated topic for discussion, leading to the 1894 drafted bill by the Criminal Law Commission on workhouses and against vagrancy, begging, and drunkenness ${ }^{81}$. The process of drafting and debating the new Vagrancy Act reveals attitudes towards and intended purposes of the existing workhouse system in its final decades.

Bernhard Getz argued very strongly against the way forced labour was imposed under the Poor Law. He found it to be inconsistent and incompatible with the principles of a constitutional state governed by law. The discretionary power of the police, he declared, was "a serious breach with the most important principles of the rule of law" to the extent that it had to be changed even without awaiting a new Criminal Code ${ }^{82}$. In the draft of the Vagrancy Bill of 1894, Getz and the Criminal Law Commission responded to the objections against the discretionary power of the police. The draft concluded that the difference between forced labour in a workhouse and regular punishment of hard labour "was so indistinguishable, that the constitutional principle according to which no one could be punished without a conviction was easily evaded, unless the same requirement to due legal process was also applied to forced labour in workhouses" $" 83$. In addition, Getz argued that many cases of detentions not only violated the Constitution, but was also in breach of the 1854 act that repealed the obligation to be in employment. This act stated that no one could be punished or treated as a vagrant if he or she subsisted without begging or being a burden to the public purse. According to Getz, this point was often not considered when the police decreed detention.

\footnotetext{
78 Olsen (1914, p. 349).

79 Getz $(1887,1893)$.

80 Getz (1892).

81 Straffelovkommissionen (1894).

82 Getz (1893, p. 119, footnote 1).

83 Straffelovkommissionen (1894, p. 16).
} 
Getz' arguments caused important changes as early as 1894 . First, police was instructed to provide accurate information as justification for each detention, and to give suspected vagrants the opportunity to explain themselves. Any decision to detain had to be protocolled with a detailed justification ${ }^{84}$. Shortly afterwards, the Department of Justice stated that drunkenness and idleness did not in themselves constitute a sufficient reason for detention; instead the suspected vagrant had to be without legal means of subsistence. Similarly to Getz, the Department also claimed that this distinction had often been ignored. They insisted that a precondition for detention should be whether the suspect or his family were a burden on society, either by receiving poor relief or by begging for a living ${ }^{85}$. The emphasis on the economic burden constituted by the detainees brought the Norwegian practice more in line with the Danish system, which also allowed administrative detention of those receiving poor relief. The precondition that the suspected vagrant should constitute a burden was closely connected to the reconceptualisation of vagrancy that was underway in Norway and elsewhere at that time, which saw unemployment as inevitable, and considered a mobile and readily available workforce to be desirable in an industrialising society.

Civil servants in the Department of Justice thoroughly scrutinised the decrees issued by the police and their justifications and often instructed the local police to improve the exactness of the justifications. The police in Bergen in western Norway was prescribed to do so as late as 1904, as the Department complained that previous practices were too general and did not convey sufficient information about the basis on which the police decided to detain people ${ }^{86}$. Obviously, the central authorities had motives other than a desire to improve the civil rights of the inmates when supervising decrees of workhouse detentions. They suspected that the municipal authorities were shifting the expenses of poor relief from the local taxpayers to the central authorities, as the latter was partly financing workhouse detentions ${ }^{87}$. This was especially the case when the local police detained old people whom the Department assumed might not be able-bodied, and thus not subjected to forced labour, but should receive regular poor relief.

The Vagrancy Act was not enacted until 1907, and in the meantime the procedures of the old Poor Law were still in effect, though the 1894 curtailment of police discretion did have an impact. In 1893, 1,108 men and 230 women were detained at the workhouse in Oslo. In 1895, the year after the curtailment, the numbers were reduced to 504 men and 119 women $^{88}$. The reduction was formidable and probably far greater than the government expected. The figures increased again for a few years (817 men and 239 women in 1897), before they once again gradually decreased. In 1906, the last year before the new Vagrancy Act came into effect, 587 men and women were detained in Oslo.

${ }_{84}$ Resolution from the Crown Prince 7.5.1894, in Love, Resolutioner, Reglementer, Instruxer, Skrivelser m.v. vedkommende Fangselsvaesenet 1814-97 (1898).

85 Ibidem.

86 NNA: Justisdepartementet, Fengselsstyret, Kontor D, Db. L0178/ 3A 115 3/1 'Opgave over innsatte i tvangsarb. anst. II 1904', JD.JNo 1560/1904.

87 NNA: S-1043 Justisdepartementet, Fengselsstyret D del 1, L0158 'Oppgave over innsatte i tvangsarbeidsanstaltene 1894-1895'3A 115 2/6, The Departementet's review of detentions from Kristiania 4. quarter 1894.

88 Forhandlinger ved den norske kriminalistforenings syvende møte i december 1912 (1912, p. 69). 
The 1894 curtailment also had an impact on the function of the workhouse by reducing its effectiveness as an instrument for social control. An important reason for the reduction in detention was the ban on voluntary entry to the workhouse by people who were not receiving poor relief. Moreover, the police were no longer allowed to honour requests from families and local communities to remove disorderly individuals who were not receiving relief. Both police and paupers seeking voluntary admission to the workhouses responded to the change by constructing a situation that did require relief. For example, some paupers would purposefully destroy their clothes during arrest so that he or she would have to ask for assistance, thereby fulfilling the requirement to be a burden on the public. In August 1894, Anton Olsen, nicknamed "Garibaldi", was arrested for being drunk in public. During the night of his arrest, he tore up his clothes, so he was "without a thread to conceal his nudity". He was provided with new clothes and detained for six months ${ }^{89}$. Similarly, a few days earlier, Johan Jarmann, aged 65, was detained in Oslo. He had never received poor relief, except when he was provided with clothes upon his release from the workhouse four weeks earlier and was thus considered by the police as a burden ${ }^{90}$. A large number of similar examples can be found in the written justifications. The police also used food given to people under arrest as proof of them being a burden. On some occasions, homeless individuals asked to sleep over in the police cells, which could likewise result in workhouse detention because the police considered such admissions as a form of relief and consequently as a burden on the municipality. On the other hand, police felt powerless in controlling prostitutes, who rarely received poor relief. This led the government to disregard the additional requirements of being a burden, and in 1895 , it proclaimed that prostitution was a legitimate reason for detaining women.

Police from all areas of Norway, but especially from the larger towns, argued against changing the practice of forced labour. In 1894, Getz's draft was distributed for comments among the local and central authorities, which resulted in widespread objections against the introduction of legal process as a requirement for detention ${ }^{91}$. Objections to such procedures were based on the increased workload and delayed detentions for the cases where detention was eventually allowed.

When the Norwegian Parliament started discussing the Vagrancy Bill in 1898, the articles on workhouses were separated from the main bill and promoted as a separate 'Prisons and Workhouses Bill' ${ }^{92}$. Both bills were debated in the parliament in 1899, and were passed and sanctioned by the king in 1900. Both were part of a major project for legal reform of social policies, which included the 1896 Child Welfare Act, the 1900 Poor Law Act, and the new Penal Code of 1902. Most of

89 NNA, S-1043, Justisdepartementet, Fengselsstyret D del 1, L0157 Toftes gave 1880-1900. 'Oppgave over innsatte i tvangsarbeidsanstalt 3. kvartal 1894. Fengselsregnskap', 11.8.1894.

90 NNA, S-1043, Justisdepartementet, Fengselsstyret D del 1, L0157 Toftes gave 1880-1900. 'Oppgave over innsatte i tvangsarbeidsanstalt 3. kvartal 1894. Fengselsregnskap', 9.8.1894.

91 NNA, Justisdepartementet, Lovavdelingen - RA/S-3212/D/De/L0080/0002, 'Erklæringer angående utkast til lov om løsgjengeri, betleri og drukkenskap samt om tvangsarbeidshuse', 1895.

92 Stortingets forhandlinger; Oth. prp. No.2: 'Ang. Lov om Løsgjængeri, Betleri og Drukkenskab' (1898-1899). [Records of Proceedings of the Storting 1898-1899; Proposition to the Storting (Bill) No.2 on Vagrancy, begging and drunkenness] and Stortingets forhandlinger; Oth. prp. No.3: 'Om Fængselsvæsen og Tvangsarbeide' (1898-1899). Records of Proceedings of the Storting 1898-1899; Proposition to the Storting (Bill) No.3 on Prisons and Workhouses]. 
these were mainly drafted by Getz and passed only with minor changes. Hence, the criticism emanating from the police was disregarded by Parliament.

Individuals subjected to punishment according to the Vagrancy Act were ablebodied persons who were a burden to the public, idle persons who were not a burden to the public, but suspected of regular acts of crime, as well as beggars, casual drunkards, and alcoholics. In this sense, the new Vagrancy Act did not differ much from the corresponding articles of the old Poor Law. The target groups seemed to be the same. However, the Vagrancy Act made changes in three different ways. First, the spirit of the old Poor Law was exclusively repressive towards the inmates. By contrast, the new law included elements relating to care and assistance. A punishment, according to the law, was not only to serve as a reprimand and a deterrent, but also to provide help and assistance to alcoholics. However, this element was severely curtailed when the law came into effect as no curative institution was established as intended. A change was also seen in the new procedures according to which idle persons first had to receive a warning by the police and had to be offered some opportunity to work before they could be punished.

Second, the act introduced legal proceedings. Court could delegate to the public prosecutor the decision to commute a prison sentence into workhouse detention very similar to the practise in the Imperial German Penal Code. The argument for this system was that the police and officials acting for the public prosecutor had the most intimate knowledge about the vagrants and therefore were most competent to assess if forced labour was necessary in individual cases and if so, for how long ${ }^{93}$. As for alcoholics, their detention required convictions for being intoxicated in public at least three times within the last year.

Third, the length of detentions was considerably extended. A first-time conviction for vagrancy or for being intoxicated in public resulted in a prison sentence or forced labour for up to eighteen months. In case of repeated convictions, the maximum sentence was normally three years, but as long as six years if the accused was suspected of committing crimes punishable with prison sentence.

The introduction of judicial decisions, with their requirements of proof being able to stand up in court, caused discontent with the act. In 1914, the chief constable in Bergen expressed the police's frustration by claiming that the need for conclusive evidence had, to a large extent, paralysed the ability of the police to protect society from vagrants ${ }^{94}$. The number of workhouse detentions indicated the effective and pragmatic nature of forced labour during the Poor Law compared with the Vagrancy Act. Each year between 1901 and 1905, an average of 735 men and 262 women were detained in workhouses in Norway ${ }^{95}$. By comparison, only 114 men and 33 women were on average were incarcerated each year between 1907 and 1913, the period

$93 \quad$ Stortingets forhandlinger; Indst. O. XIX. (1898-1899, p. 5). [Records of Proceedings of the Storting 1898-1899; Recommendation No.19 from the standing Social Questions Committee regarding bill on Vagrancy, begging and drunkenness] and Stortingets forhandlinger; Oth. prp. No.2: 'Ang. Lov om Løsgjængeri, Betleri og Drukkenskab' (1898-1899, p. 15). [Records of Proceedings of the Storting; Proposition to the Storting (Bill) No. 2 on Vagrancy, begging and drunkenness].

94 Olsen (1914, p. 350).

95 The figures are collected from the Official Statistics of Norway, Norges offisielle statistikk, Fengselsstyrelsens Aarbog, Kristiania [Oslo] 1901-1906 [Official Statistics of Norway] with data from 19011906. The figures show the number of inmates excluding men incarcerated according to the law on fathers' obligation to pay maintenance for children from 1892. 
that followed the introduction of the Vagrancy Act. The dramatic reduction can partly be explained by the increased duration of detention. However, the figures also demonstrate that the new requirements for evidence were obstructing the police in their task of cleansing the streets.

By introducing the judicial verdicts, the Vagrancy Act for the most part represented a change in shape rather than in actual content concerning the deprived groups among the marginalised proletariat of the towns. The main target groups and the purpose of detention remained the same, though the spiral of detention was slowed by the judicial proceedings. At the time, alcoholism was beginning to be regarded as an illness. In reality, however, the target groups of the Vagrancy Act were still considered a source of disorder that had to be disciplined and detained, and not conceived as sick patients in need of treatment.

\section{CONCLUSIONS}

Detentions in workhouses on the basis of discretionary police decrees without involvement of the judiciary and legal system served a multiplicity of functions. This is the reason why the practice remained largely uncontroversial for so long. Detention was a flexible solution for the police to intervene against "the dangerous class", and the workhouse inmates were regarded both by the police and by the public as outcasts of society, even ranking below most criminals. The Poor Law was a very efficient instrument to cleanse the streets of troublemakers and habitual criminals whose criminal acts were difficult to prove in court. Furthermore, the workhouse provided an opportunity for neighbours and families to shift the responsibility for disorderly individuals to the authorities. At the same time, the workhouse constituted a last resort for destitute paupers. Only towards the end of the nineteenth century was this practice seriously questioned, leading to the abolition of the discretionary workhouse system in Norway. However, the motives behind this change were not based on concerns for the paupers and vagrants who were subjected to detention. Rather, it was a professional project initiated by Bernhard Getz, a leading legal scholar and Director General of Public Prosecution, to adapt the legislation to comply with the principles on the rule of law and counteract the duality between protection of civil liberties and the need for effective public order policing which prevailed in contemporary liberal jurisprudence. Finally, a reconceptualisation of vagrancy stemming from the changing needs of a modernising labour market helped to bring about reforms that distinguished clearly between involuntary unemployment and vagrancy. The Vagrancy Act of 1907 had the same repressive and controlling purpose as the Poor Law of 1845 . Similarly the key target groups remained the same until the law was repealed in 1970, although the Vagrancy Act turned out to be less efficient because formal police discretion was curtailed.

Dr. Frode Ulvund

Department of Archeology, History, Cultural Studies and Religion

P.O.Box 7805

NO-5020 BERGEN

Norway

frode.ulvund@uib.no 


\section{REFERENCES}

Andersen, L., Et socialt onde eller selvforskyldt elendighed? Om begrebet arbejdsløshed

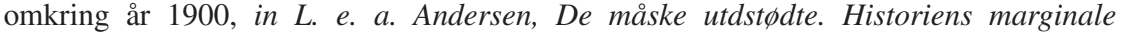
eksistenser, Aalborg Universitetsforlag, 2005.

Betcenkning og Indstilling fra den ved Kongelig Resokution af 5te August 1853 nedsatte Commission angaaende det offentlige Fattigvaesen pasa Landet, Christiania [Oslo], 1856

Blom, G. P., Bassøe, P. F., Underdanigst Indberetning fra Amtmand G. P. Blom om hans Reise $i$ Udlandet til Undersøgelse af Fattigvasenet og dets Lovgiving tilligemed Prast P. F. Bassфes Fremstilling af den Engelske Fattiglovgivning, Drammen, 1844.

Forhandlinger ved den norske kriminalistforenings andet mфde i oktober 1893, Kristiania [Oslo], 1894.

Forhandlinger ved den norske kriminalistforenings tredie mфde i november 1894, Kristiania [Oslo], 1895.

Forhandlinger ved den norske kriminalistforenings syvende mote i december 1912, Kristiania [Oslo], 1912.

Foyster, E. A., Marital violence: an English family history, 1660-1875, Cambridge, New York, Cambridge University Press, 2005.

Frohman, L., Poor relief and welfare in Germany from the Reformation to World War I, Cambridge, Cambridge University Press, 2008.

Garrioch, D., Neighbourhood and community in Paris, 1740-1790, Cambridge, New York, Cambridge University Press, 1986.

Getz, B., Forelфbigt udkast til almindelig borgerlig straffelov for kongeriget Norge. F $\phi r s t e$ del med Motiver, Kristiania, 1887.

Getz, B., Udkast til lov om sadelig forkomne og vanvyrdede børns behandling med motiver, Kristiania, 1892.

Getz, B., Udkast til almindelig borgerlig straffelov for kongeriget Norge, Kristiania, 1893.

Hippel, R. v., Verbrechen und Vergehen wider die öffentliche Ordnung, Berlin, Liebmann,1906.

Hval, A., 'Om forbryderens vilkår', Nordisk Tidsskrift for Fangselsvaesen og фvrige penitenticere institutioner, 1884.

Kielland, A. L., Den kombinerede Indretning, Stavanger, [s.n.], 1889.

Lawrence, P., Policing the Poor in England and France, 1850-1900, in Social Control in Europe, vol 2, 1800-2000, Chicago, Ohio State University Press, 2004.

Lippuner, S., Bessern und verwahren: die Praxis der administrativen Versorgung von "Liederlichen" und "Arbeitsscheuen" in der thurgauischen Zwangsarbeitsanstalt Kalchrain (19. und frühes 20. Jahrhundert), Frauenfeld, Verlag des Historischen Vereins des Kantons Thurgau, 2005.

Lis, C., Soly, H., Disordered lives: eighteenth-century families and their unruly relatives, Cambridge, UK, Cambridge, Mass., Polity Press, 1996.

Love, Resolutioner, Reglementer, Instruxer, Skrivelser m.v. vedkommende Fangselsvasenet 1814-97, Christiania [Oslo], 1898.

Midré, G., Bot, bedring eller brфd? Om bedømming og behandling av sosial nфd fra reformasjonen til folketrygden, Oslo, Rådet for samfunnsvitenskapelig forskning i NAVF, Universitetsforlaget, 1990.

Monkkonen, E. H., The dangerous class : crime and poverty in Columbus, Ohio, 1860-1885, Cambridge, Mass., Harvard University Press, 1975.

Nilsson, R., Kontroll, makt och omsorg: sociala problem och socialpolitik $i$ Sverige 17801940, Lund, Studentlitteratur, 2003. 
Norges offisielle statistikk, Tredie Række No. 73, Oversigt over de vigtigste Resultater af Norges Kriminalstatistikk for Aarene 1846-85. Kristiania [Oslo] 1888 [Official Statistics of Norway].

Norges offisielle statistikk, Fengselsstyrelsens Aarbog, Kristiania [Oslo] 1901-1906 [Official Statistics of Norway].

Olsen, J., 'Politivæsen, strafferetspleien, fængsel, strafanstalter m.v.', in Bergen 1814-1914, Bergen, 1914.

Om istandbringelse af nye tvangsarbeidsanstalter: indstilling fra den af Justisdepartementet 28de september 1905 nedsatte komite, Kristiania, [s.n.], 1907.

Omsted, A., Prinds Christian Augusts minde : en historisk fremstilling, Kristiania, 1911.

Petrow, S., Policing morals: the Metropolitan Police and the Home Office, 1870-1914, Oxford, Clarendon Press, 1994.

Rosenblum, W., Beyond the prison gates: Punishment and welfare in Germany, 1850-1933, Chapel Hill, The University of North Carolina Press, 2008.

Seip, A.-L., Sosialhjelpstaten blir til : norsk sosialpolitikk 1740-1920, Oslo, Gyldendal, 1994.

Sleebe, V., 'Community and Social Control: An Enquiry into the Dutch Experience', in Social Control in Europe, vol 2, 1800-2000, Columbus, Ohio State University, 2004.

Stortingets forhandlinger, Indst. O. No 28, 1862-1863. [Records of Proceedings of the Storting 1862-1863. Recommendation No.28 from the standing Church Committee].

Stortingets forhandllinger; Forhandlinger i Odelstinget, 8. del, 1892. [Records of Proceedings of the Storting 1892; Parliamentary debate].

Stortingets forhandlinger; Oth. prp. No.2, 1898-1899. [Records of Proceedings of the Storting 1898-1899; Proposition to the Storting (Bill) No.2].

Stortingets forhandlinger; Oth. prp. No.3, 1898-1899. [Records of Proceedings of the Storting 1898-1899; Proposition to the Storting (Bill) No.3].

Stortingets forhandlinger; Indst.O.XIX, 1898-1899 [Records of Proceedings of the Storting 1898-1899; Recommendation No.19 from the standing Social Questions Committee].

Stortingets forhandlinger; Dokument 100, 1899-1900. [Records of Proceedings of the Storting 1898-1899; Document No 100].

Stortingets forhandlinger; Oth. prp No.14, 1914. [Records of Proceedings of the Storting 1914 ; Proposition to the Storting (Bill) No.14].

Straffelovkommissionen, Udkast til Lov om Løsgjaengeri, Betleri og Drukkenskab samt om Tvangsarbeidshuse, Kristiania, 1894.

Sundt, E. and H. O. Christophersen, Verker i utvalg. 11, Om fattigforholdene i Christiania, Oslo, Gyldendal, 1978.

Ulvund, F, "Byens Udskud"?: ein studie av karrierar som innsett i tvangsarbeids- og straffanstaltar i Bergen ca. 1850-75, Ph.d thesis, University of Bergen 2002.

Ulvund, F, "At rense gaterne", Tvangsarbeid som disiplinering og sosial kontroll før 1907, in Virker straff?, forthcoming anthology at Scandinavian Academic Press 2012.

Wallentin, H., Lösdriveri och industrialism: om lösdriverifrågan i Sverige 1885-1940, Östersund, Högskolan i Östersund, 1989. 